\title{
PLAGIOTHECIUM LATEBRICOLA, A NEW MEMBER OF THE HUNGARIAN BRYOFLORA
}

\author{
Peter ErzBergeR ${ }^{1}$ and Kornél BARÁTH ${ }^{2}$ \\ ${ }^{1}$ Belziger Str.37,D-10823 Berlin, Germany; erzberger.peter@gmail.com \\ ${ }^{2}$ Institute of Biology, Savaria Campus, Eötvös Loránd University, \\ H-9700 Szombathely, Károlyi Gáspár tér 4, Hungary
}

Erzberger, P. \& Baráth, K. (2017): Plagiothecium latebricola, a new member of the Hungarian bryoflora. - Studia bot. hung. 48(2): 189-197.

\begin{abstract}
During the systematic field studies aimed at exploring the recent bryophyte flora of the Köszeg Mts and in the framework of grid-cell based bryophyte recording, Plagiothecium latebricola Schimp. was discovered in the Köszeg Mts. The size of the population is estimated and the habitats are characterized. Illustrations, a short description and a taxonomic key are provided to distinguish it from the other species of Plagiothecium in Hungary. Although P. latebricola might possibly be found in other parts of the country as well, it is known only in one location so far. Consequently, the species should be considered as critically endangered (CR).
\end{abstract}

Key words: bryophyte diversity, Hungary, Kőszeg Mts, moss species, new record

\section{INTRODUCTION}

Plagiothecium latebricola was described by SCHIMPER (1851) based on material collected by W. Wilson in England (Warrington, Cheshire, VC 58), but according to the protologue the first, although sparse collection ("parcissime") was made by W. Mitten in Sussex (SCHIMPER 1851). Wilson (in manuscript and later in his Bryologia Brittanica - WiLson 1855) named the plant Leskea latebricola, the "lurking Leskea". The specific epithet (latebrae, lat.: hiding place) refers to a hidden kind of habitat.

Unlike the members of the Leskeaceae family, which usually possess a costa and have short cells, 1-2 (rarely up to 5) times as long as wide, and often papillose or prorate, $P$. latebricola has ecostate leaves and smooth cells that are 8-15 times as long as wide. Its leaves are less clearly complanate than in other members of Plagiothecium, but are decurrent along the stem in an alar group that usually remains attached to the stem when leaves are removed, a character also found in other members of Plagiothecium. Schimper's generic placement has been universally accepted, although FLEISCHER (1900-1922) and after him Brotherus (1924-1925) made the combination Plagiotheciella latebricola (Schimp.) M. Fleisch. 
Plagiothecium latebricola is widespread in Europe except in the South, and also occurs in Turkey, Georgia, Kyrgyzstan, Siberia to East Asia, Japan, and in Eastern North America (Hodgetts 2015, Hodgetts and Blockeel 2014). Among the countries surrounding Hungary, the species occurs in Austria, Serbia, Romania, Ukraine and Slovakia. It is red-listed in Austria (2), Romania (CR) and Slovakia (CR) (HodgetTs 2015).

\section{MATERIAL AND METHODS}

Extensive field studies were conducted between 2015 and 2017 to investigate the bryophyte diversity and distribution patterns in the Köszeg Mts. Geographical coordinates of the P. latebricola population were determined using a Garmin eTrex-30 GPS. The nomenclature of the bryophyte taxa follows PAPP et al. (2010) and Hodgetts (2015). In the case of the vascular plants the nomenclature follows KIRÁLY (2009).

\section{RESULTS AND DISCUSSION}

During the bryological exploration of the Köszeg Mts (BARÁTH and ERZBERGER 2017a) within the framework of grid-cell based bryophyte recording (ERZBERGER and NÉMETH 2016), A. Mesterházy guided the authors to the valley of the stream Hármas-patak below Stájer-házak, which here forms the border to Austria. On that very occasion Rhabdoweisia crispata (Dicks. ex With.) Lindb. was found new to the Hungarian bryoflora (MEsterházy et al. 2017). During the following weeks, Kornél Baráth paid several more visits to this area, upon which he found another novelty for Hungary, Heterocladium heteropterum (Brid.) Schimp. (BARÁTH and ERZBERGER 2017b). On one of these visits, he collected a very small amount of a minute pleurocarp, which he sent to Peter Erzberger for determination. This turned out to be the first collection of P. latebricola in Hungary. There is an interesting parallel between this collection history and the first ever collections of the species mentioned above. During a later visit of the authors to the area the species was found on several alder tree trunks. Here are the details:

Hungary: Vas County, Köszeg Mts [8664.2] ca $5 \mathrm{~km}$ west of the town of Köszeg, ca 10-30 m from the border to Austria, in alder carr along the stream Hármas-patak below Stájer-házak, at the base of Alnus glutinosa trees, on bark and partly decayed wood particularly in recesses between roots, ca $360 \mathrm{~m}$ a.s.l., $47.38675^{\circ} \mathrm{N}, 16.45592^{\circ} \mathrm{E}, 14$ October 2016; leg.: P. Erzberger and K. Baráth (B-Erzberger 22303, 22304, hb. Baráth, dupl. hb. Németh, BP); earlier collected from near this site 15 July 2016, leg. K. Baráth, det. P. Erzberger 22 July 2016, 
conf. L. Meinunger \& W. Schröder 16 August 2016 (B-Erzberger s.n.). Altogether seven colonies of $P$. latebricola covering an overall area of $c a 800 \mathrm{~cm}^{2}$ were found along the stream Hármas-patak (Figs 1-3).

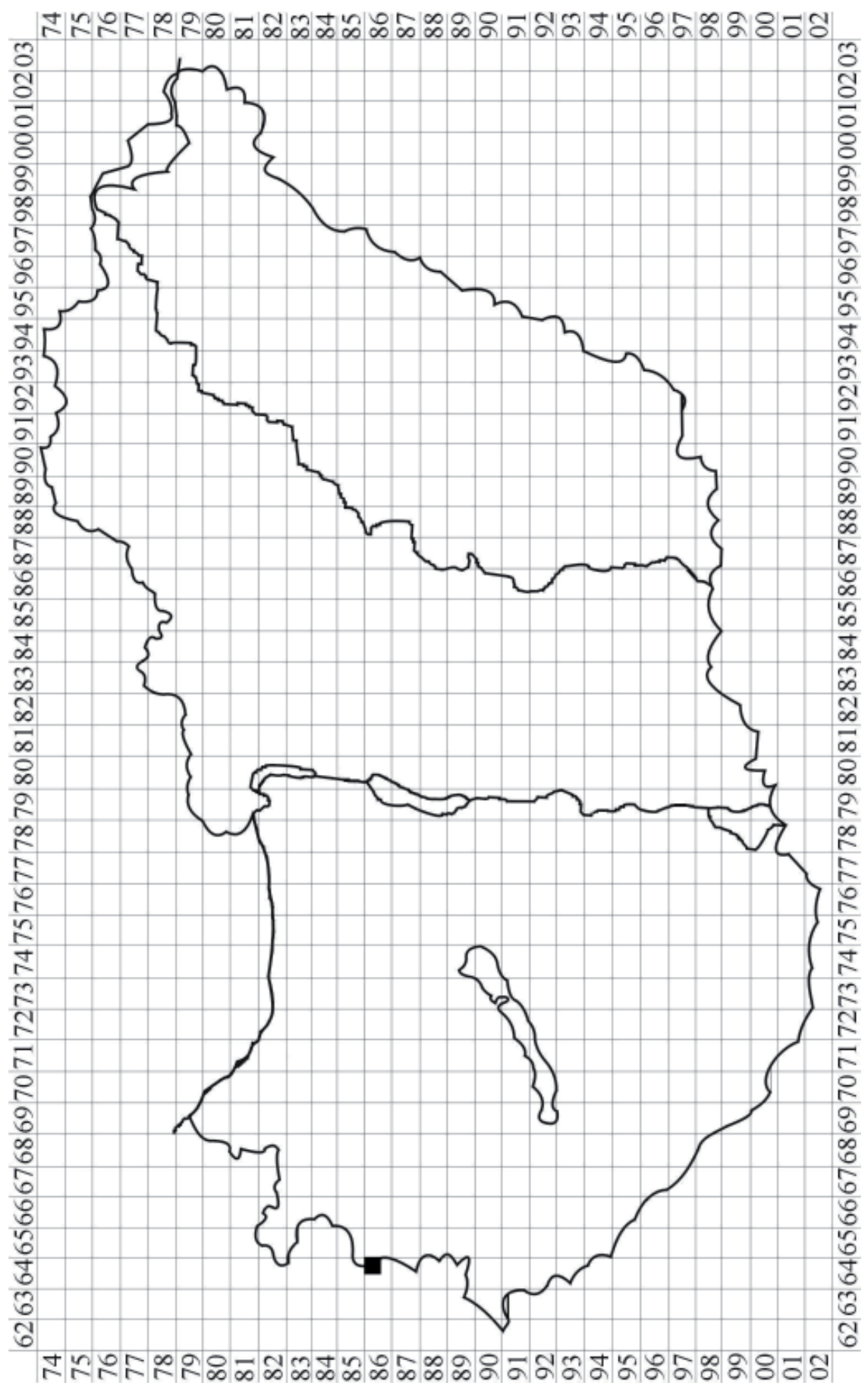


We assume that the newly discovered occurrence is not the only one in Hungary, although the species is a strict calciphobe, and therefore more likely to occur in regions with acidic underground (e.g. Somogy County) than in regions with lime-containing deposits (e.g. the calcareous sands of the Duna-Tisza interfluve). We would like to encourage all field botanists in Hungary to search for this interesting plant in alder carr at the base of alder trees.

In Austria, only four records of $P$. latebricola are known, one of them from “Günser Gebirge” (Kőszeg Mts) near the Hungarian border, between Bad Tatzmannsdorf and Stadtschlaining, collected by J. Poelt (GRIMs 1999).

Since there are now 9 species of Plagiothecium known to occur in Hungary, we include a key for the genus:

1 Leaves transversely undulate; laminal cells arranged in transverse rows .................................... 2

Leaves not transversely undulate; laminal cells not in distinct transverse rows ......................... 3

2 Leaves whitish green, $2-5 \mathrm{~mm}$ long, imbricate, strongly transversely undulate; decurrent alar cells with straight outer walls; on forest soil ............................. P. undulatum (Hedw.) Schimp. Leaves light to yellowish green, $2-2.6(-3) \mathrm{mm}$ long, loosely foliate, not imbricate; decurrent alar cells with bulging outer walls; plants of wet habitats P. ruthei Limpr.

3 Median laminal cells narrow, $<10 \mu \mathrm{m}$ wide; small plants, usually only $2-3 \mathrm{~cm}$ long .............. 4 Median laminal cells $>10 \mu \mathrm{m}$ wide; medium-sized to large plants

4 Leaves $0.9-1 \mathrm{~mm}$ long and $c a 0.35 \mathrm{~mm}$ wide, gradually acuminate to a long point, often with uniseriate gemmae and rhizoids at the tip; laminal cells $5(-8) \mu \mathrm{m}$ wide .. P. latebricola Schimp. Leaves longer and wider (mostly $>0.5 \mathrm{~mm}$ wide), apex less longly drawn out, without gemmae at leaf tip (but gemmae frequent in leaf axils); laminal cells wider

5 Leaf apices plane; leaves to $1.2 \mathrm{~mm}$ long, alar cells decurrent in 1-2 rows, not clearly delimited, not auriculate, with straight outer walls, rectangular ............................ P. laetum Schimp. Leaf apices curved downward towards substrate when moist; leaves $>1.2 \mathrm{~mm}$ long, alar cells forming a distinct group, decurrent in $2-4(-5)$ rows, mostly somewhat auriculate, often with weakly bulging outer walls, isodiametric or rectangular; capsule horizontal to inclined, often gibbous P. curvifolium Schlieph. ex Limpr.

6 Alar cells inflated, oval to rounded, with bulging walls, decurrent along stem ........................ 7 Alar cells not inflated, the decurrent cells rectangular, not rounded .......................................... 8

7 Apical part of lamina usually with a group of thin-walled cells (rhizoid initials) often eroded; some leaves only weakly asymmetric; large plants to $10 \mathrm{~cm}$ long .......... P. platyphyllum Mönk. Leaves without rhizoid initials at apex; all leaves distinctly asymmetric; medium-sized plants P. denticulatum (Hedw.) Schimp.

8 Leaves \pm symmetric, concave; plants julaceous, decumbent (examine older plants; young plants of other species can look similar); mid-leaf cells (8-)10-12(-15) $\times 65-120(-150) \mu \mathrm{m}$. P. cavifolium (Brid.) Z. Iwats.

Leaves \pm asymmetric, plane; mid-leaf cells wider or longer ... 9

9 Majority of mid-leaf cells longer than $150 \mu \mathrm{m}$ and $10-20 \mu \mathrm{m}$ wide (7-10 times as long as wide), not in transverse rows; apical end cell linear, elongate; leaf apex occasionally with rhizoid initials P. succulentum (Wilson) Lindb.

Mid-leaf cells $15-22(-25) \times(65-) 75-140(-155) \mu \mathrm{m}(4-6$ times as long as wide) in \pm transverse rows; apical end cell rhomboidal; leaf apex usually with (few) rhizoid initials

P. nemorale (Mitt.) A. Jaeger 
From all other Plagiothecium species P. latebricola is distinguished by its small size, stems to $2 \mathrm{~cm}$ long and $0.5-1 \mathrm{~mm}$ wide across leafy stem. It is even smaller than Isopterygiopsis pulchella (Hedw.) Z. Iwats., to which it also shows some resemblance (Fig. 4). The leaves are ovate lanceolate, symmetric, (0.7-)0.9-1 $(-1.5) \mathrm{mm}$ long and $0.3-0.45 \mathrm{~mm}$ wide, longly and gradually acuminate. Median leaf cells are 5-6(-8) $\mu \mathrm{m}$ wide and 70-100(-120) $\mu \mathrm{m}$ long, thin-walled, not pitted. Alar cells are in a flat, longly decurrent group, rectangular, ca $20 \mu \mathrm{m}$ wide. Often filiform gemmae, ca $100 \mu \mathrm{m}$ long and ca $10 \mu \mathrm{m}$ wide, formed of 3-4(-5) cylindrical cells, are found in clusters at the leaf tip (Figs 5-6). The plants are dioicous, and capsules are very rarely produced. The small, dense, often somewhat scrubby mats are pale to yellowish green, \pm glossy. They grow on acidic tree bark, most typically at the base of alder trees (Alnus glutinosa) in recesses between the roots (Fig. 3), on bark that is already in some state of decay; more rarely on

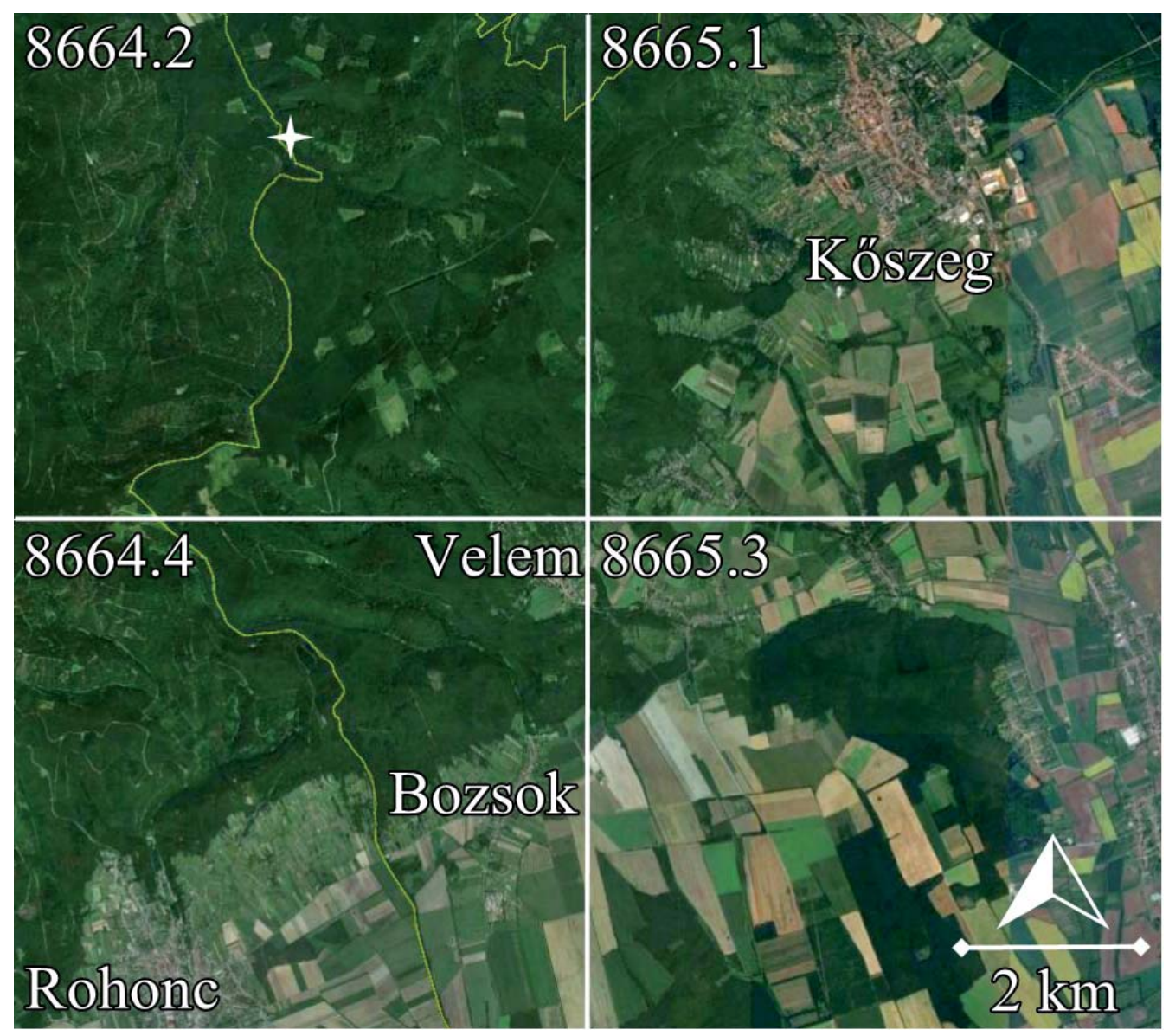

Fig. 2. Geographical location of the population of Plagiothecium latebricola in the Köszeg Mts. 


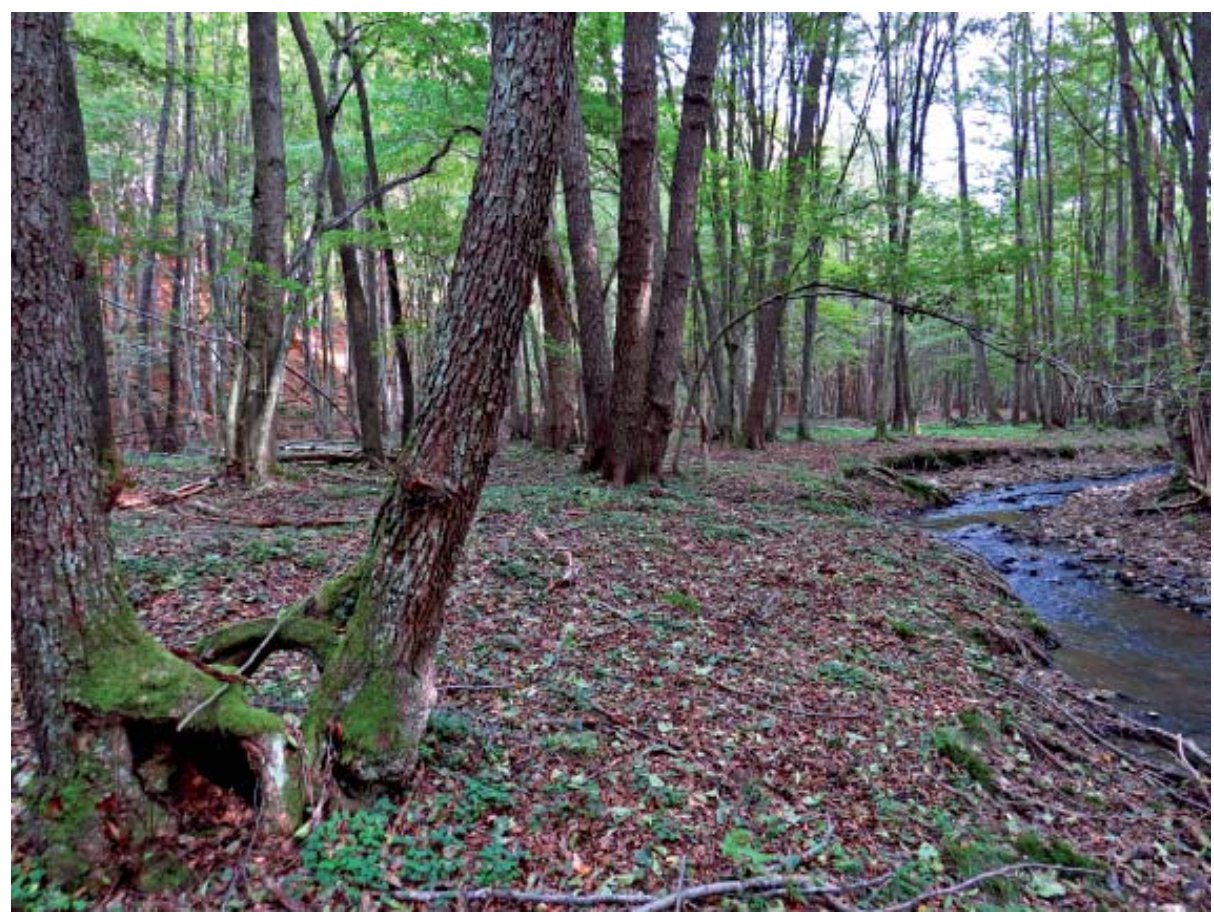

Fig. 3. Habitat of Plagiothecium latebricola at the stream Hármas-patak near Kőszeg.

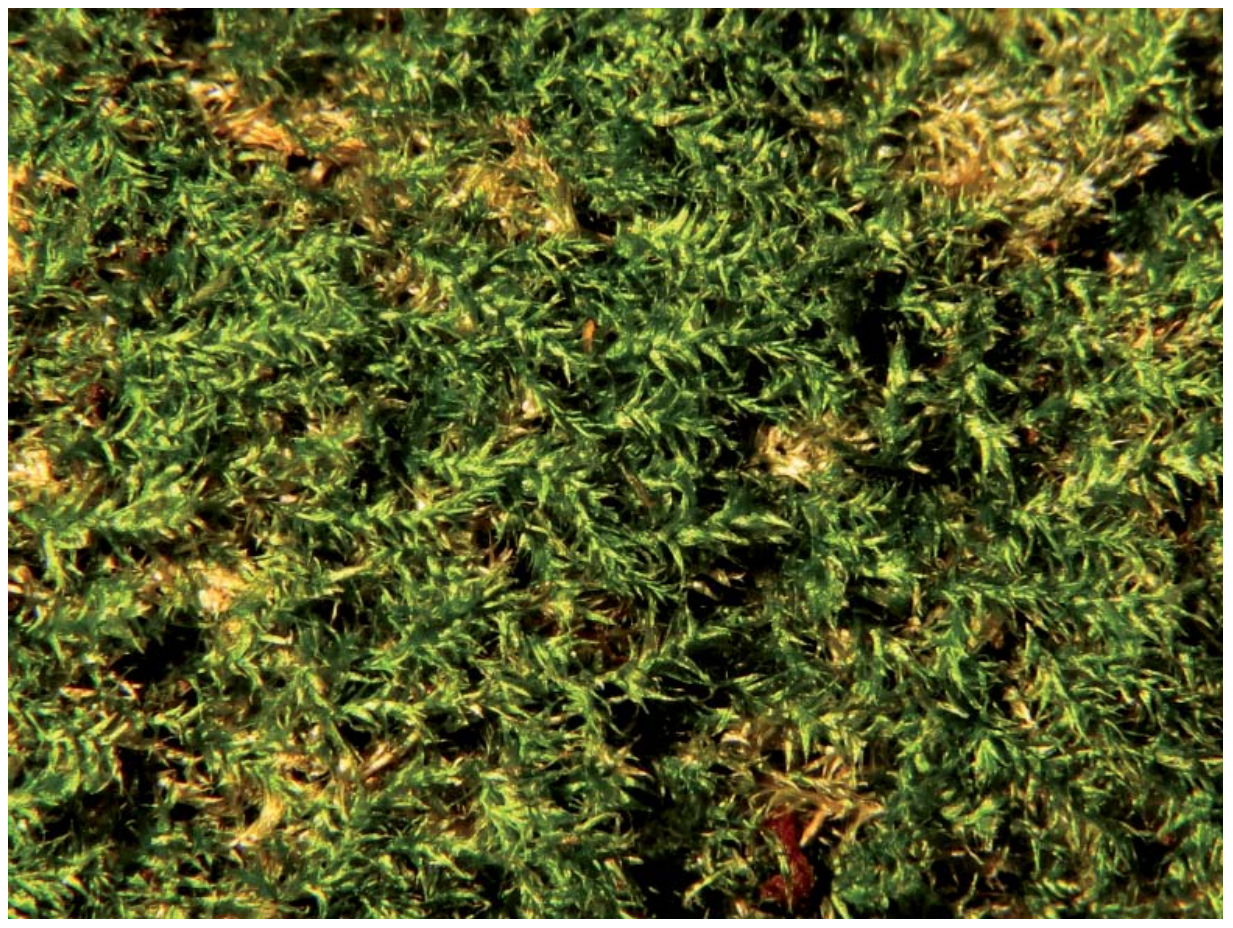

Fig. 4. Habit of Plagiothecium latebricola. 


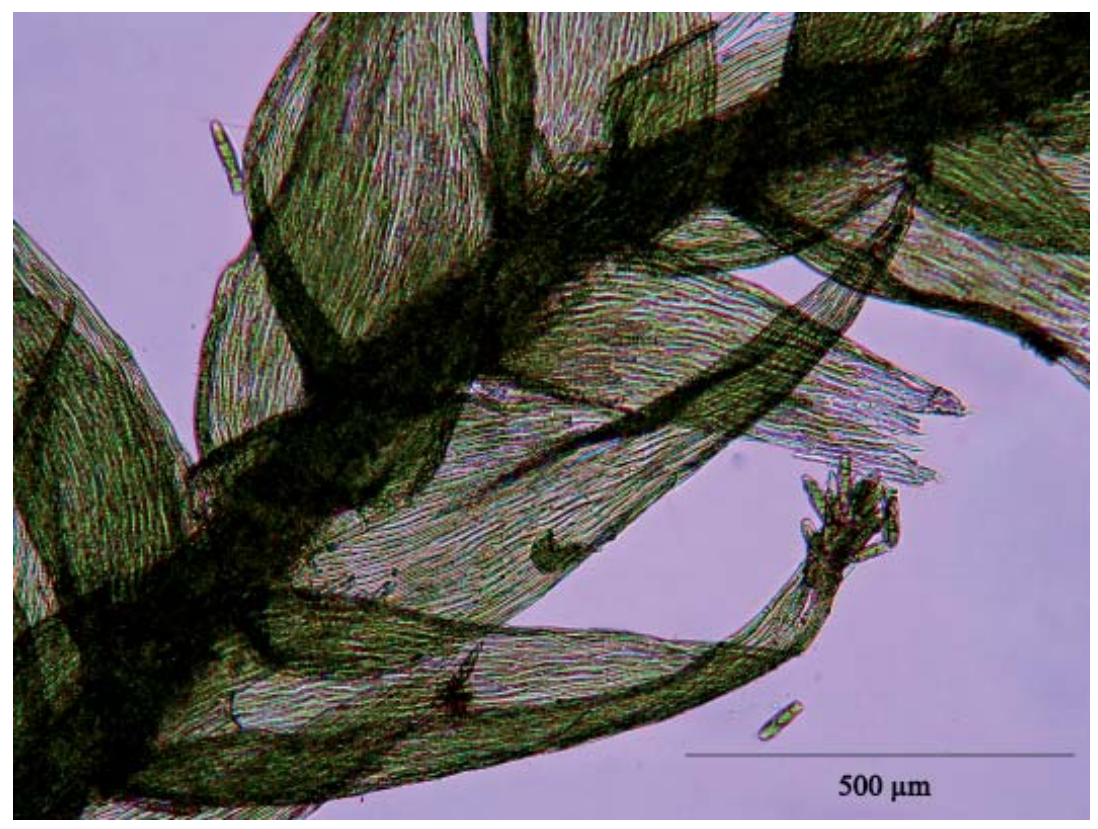

Fig. 5. Plagiothecium latebricola - microscopic detail.

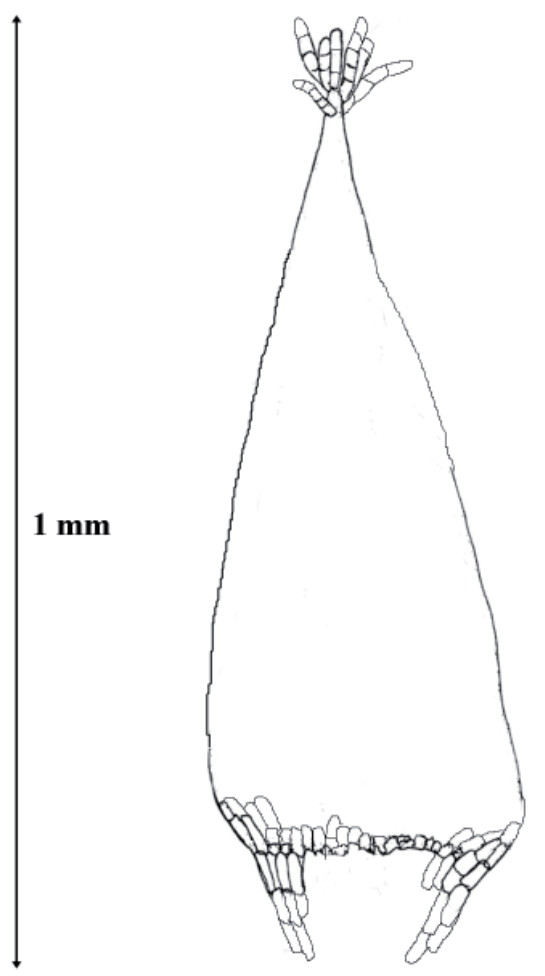

Fig. 6. Plagiothecium latebricola - leaf with apical gemmae. 
Carex tussocks and fern stools, on acidic humus, lime-free soil or acidic rocks. The sites must have high air humidity. P. latebricola is a characteristic plant of lowland alder carr. However, its stands are usually small, and will be found only if directly searched for. According to the results of the German recording project (MEINUNGER and SCHRÖDER 2007), even in Germany there are areas where the species could be expected but seems to be still overlooked. Although P. latebricola might possibly be found in other parts of the country as well, it is known only in one location so far. Consequently, the species should be considered as critically endangered (CR).

Acknowledgements - We thank L. Meinunger and W. Schröder, Ludwigsstadt (Germany), for confirming the identity of $P$. latebricola.

Összefoglaló: A Kőszegi-hegység mohaflóráját feltáró terepmunkák során 2016-ban egy újabb, Magyarországra nézve új mohafaj került elő. A Plagiothecium latebricola előfordulására számítani lehetett, hiszen Ausztriában, Szerbiában, Romániában, Ukrajnában és Szlovákiában is előfordul, ráadásul legjellemzőbb élőhelye Magyarországon sem számít ritkaságnak. A faj leggyakrabban erősen korhadó mézgás égerfák tövén található. A Kőszegi-hegységben ez idáig hét telepet találtunk, amelyeknek az együttes kiterjedése $c a 800 \mathrm{~cm}^{2}$ volt. A Plagiothecium latebricola a többi Plagiothecium-fajtól leginkább mérete és a levélcsúcson található fonalas gemmái alapján különíthető el. Habár a faj valószínủleg az ország más részein is megtalálható, jelenleg csupán egyetlen lelőhelye ismert, ezért a magyarországi vörös listán a súlyosan veszélyeztetett kategóriába sorolandó.

\section{REFERENCES}

BARÁth, K. and ERzberger, P. (2017a): A mohaflóra terepi felmérésének első eredményei a Köszegi hegységben. - Bot. Közlem. 104(1): 166-167.

BARÁth, K. and Erzberger, P. (2017b): 16. Heterocladium heteropterum (Brid.) Schimp. [Hungary]. In: Ellis, L. T. (ed.): New national and regional bryophyte records, 50. - J. Bryol. 39: 99-114. https://doi.org/10.1080/03736687.2016.1259931

Brotherus, V. F. (1924-1925): Musci. - In: Engler, H. G. A. et al. (eds): Die Natürlichen Pflanzenfamilien 11: 1-535.

ERzBerger, P. and NÉMeTH, Cs. (2016): Bryophyte recording in Hungary - results 2012-2015. 11 th International Conference "Advances in research on the flora and vegetation of the Carpato-Pannonian region”, Budapest, 12-14 February 2016 (lecture), Book of Abstracts, p. 17.

Fleischer, M. (1900-1922): Die Musci der Flora von Buitenzorg. Zugleich Laubmoosflora von Java mit Berücksichtigung aller Familien und Gattungen der gesamten Laubmooswelt (Flore de Buitenzorg, Partie V, 1900-1922) - Leiden. Reprint 1976 Bryophytorum Bibliotheca 9: $1-1760$.

Grims, F. (1999): Die Laubmoose Österreichs. Catalogus Florae Austriae, Teil 2, Bryophyten (Moose). Heft 1, Musci (Laubmoose). - Biosystematic and Ecology Series 15: 1-418.

HodgetTs, N. G. (2015): Checklist and country status of European bryophytes - towards a new Red List for Europe. - Irish Wildlife Manuals 84: 1-124. 
Hodgetts, N. G. and Blockeel, T. L. (2014): Plagiothecium latebricola. - In: Blockeel, T. L., Bosanget, S. D. S., Hill, M. O. and Preston, C. D. (eds): Atlas of British and Irish bryophytes, the description and habitat of mosses and liverworts in Britain and Ireland 2. Pisces publications on behalf of the British Bryological Society, Newbury, Berkshire, $572 \mathrm{pp}$.

KIRÁLY, G. (ed.) (2009): Új magyar füvészkönyv. Magyarország hajtásos növényei. Határozókulcsok. - Aggteleki Nemzeti Park Igazgatóság, Jósvafő, 616 pp.

MeInUnger, L. and SCHRöDer, W. (2007): Verbreitungsatlas der Moose Deutschlands. Vol. 1-3. Regensburgische Botanische Gesellschaft, Regensburg, 636+699+709 pp.

Mesterházy, A., Baráth, K. and Erzberger, P. (2017): 26. Rhabdoweisia crispata (Dicks. ex With.) Lindb. [Hungary]. In: Ellis, L. T. (ed.): New national and regional bryophyte records, 50. - J. Bryol. 39: 99-114. https://doi.org/10.1080/03736687.2016.1259931

PApp, B., Erzberger, P., Ódor, P., Hock, Zs., Szövényi, P., Szurdoki, E. and Tóth, Z. (2010): Updated checklist and red list of Hungarian bryophytes. - Studia bot. hung. 41: 31-59.

SCHIMPER, W. P. (1851): Plagiothecium latebricola. - In: BRUCH, P. and SCHIMPER, W. P. (18361855): Bryologia Europaea seu genera muscorum europaeorum monographice illustrata. Vol. 5. Schweizerbart, Stuttgart, 1526 pp. (reprint 1971, rearranged by P. A. Florschütz and W. D. Margadant).

Wilson, W. (1855): Bryologia Brittanica; containing the mosses of Great Britain and Ireland, systematically arranged and described according to the method of Bruch and Schimper, with illustrative plates: being a new (third) edition, with many additions and alterations, of The Muscologia Brittanica of Messrs. Hooker and Taylor. - Longman, Brown, Greene and Longmans, London, 445 pp. +61 plates.

(submitted: 01.10.2017, accepted: 09.11.2017) 